\title{
Pharmacognosy \\ Phytochemical study and antioxidant activity of Dalbergia ecastaphyllum
}

\author{
Cátia Ionara Santos Lucas ${ }^{1,4,5}$, Adailton Freitas Ferreira ${ }^{1,2}$, Maria Angélica Pereira de Carvalho Costa ${ }^{1}$, \\ Fabiane de Lima Silva ${ }^{1}$, Leticia Miranda Estevinho ${ }^{3}$ \& Carlos Alfredo Lopes de Carvalho ${ }^{1}$
}

\begin{abstract}
The chemical profile of Dalbergia ecastaphyllum has been indicated as the botanical origin of Brazilian red propolis, an apicultural product with proven therapeutic properties. However, few studies have investigated this plant species. This study evaluated and compared microbiological quality, chemical composition, and antioxidant activity of stem and leaf samples of D. ecastaphyllum. The samples were collected in February 2015, in the southern region of the state of Bahia, Brazil. We performed the microbiological analyses, determined the contents of fatty acid, total phenol and flavonoid, and identified the chemical profile and antioxidant activit. Escherichia coli, Salmonella spp. and sulfite reducing clostridial spores were not detected in the samples. Acids of the family $\omega 3$ were recorded in the stems and $\omega 6$ in the leaves. The leaves presented better nutritional quality of the fraction, better antioxidant capacity in the tests by the DPPH method and $\beta$-carotene bleaching. There were 49 chemical compounds, of which 38 belonged to the class of flavonoids. The results indicate that stems and leaves of D. ecastaphyllum have biological properties. Leaves particularly are better for functional food formulation and as natural antioxidant.
\end{abstract}

Key words: DPPH, fatty acids, flavonoids, LC-MS, omega- 6.

\section{Resumo}

O perfil químico de Dalbergia ecastaphyllum tem sido indicado como a provável origem botânica da própolis vermelha brasileira, um produto apícola com inúmeras propriedades terapêuticas comprovadas. No entanto, existem poucas pesquisas dedicadas a esta espécie de planta. O objetivo deste estudo foi avaliar e comparar a qualidade microbiológica, composição química e atividade antioxidante de amostras de caule e folhas de D. ecastaphyllum. As amostras foram coletadas em fevereiro de 2015, na região sul do estado da Bahia, Brasil. Análises microbiológicas, determinação de ácidos graxos, conteúdo total de fenóis e flavonoides, identificação do perfil químico e atividade antioxidante foram realizados. Escherichia coli, Salmonella spp. e esporos de clostridios redutores de sulfito estavam ausentes em todas as amostras. Ácidos da família $\omega 3$ foram registrados nos caules e $\omega 6$ nas folhas. A folha apresentou melhor qualidade nutricional da fração, melhor capacidade antioxidante nos testes pelo método DPPH e branqueamento $\beta$-caroteno. Foram encontrados 49 compostos químicos, dos quais 38 pertenciam à classe dos flavonoides. Os resultados indicam que o caule e a folha de D. ecastaphyllum possuem propriedades biológicas, particularmente as folhas são melhores para uso na formulação de alimentos funcionais e como antioxidante natural.

Palavras-chave: DPPH, ácidos graxos, flavonoides, LC-MS, ômega-6.

\footnotetext{
${ }^{1}$ Universidade Federal do Recôncavo da Bahia, Depto. Ciências Agrária, Biológicas e Ambientais, Grupo de Pesquisa Insecta, R. Rui Barbosa 710, Centro, Cruz das Almas, BA, Brasil.

${ }^{2}$ Centro Universitário de Tecnologia e Ciências - UniFTC, Depto. Engenharia Ambiental, Av. Artêmia Pires s/n, Feira de Santana, BA, Brasil.

${ }^{3}$ Polytechnic Institute of Bragança, Agricultural College of Bragança, Campus de Santa Apolónia, 5300-253, Bragança, Portugal.

${ }^{4}$ ORCID: <https://orcid.org/0000-0001-8975-4703>

5 Author for correspondence: catiaionara@gmail.com
} 


\section{Introduction}

Dalbergia ecastaphyllum (L.) Taub. belongs to the Fabaceae family and is widely distributed along the coast of the Americas (from southern Florida to southern Brazil) as well as on the eastern coast of the African continent. The occurrence of this species is usually associated with areas of riverbeds, mangroves and restinga vegetation (Carvalho 1997). Dalbergia ecastaphyllum has a growth of liana shrub, incandescent or semiprostrate and presents a tangle of branches and a stem that contributes to better fixation (Lima 2015).

This species is widely used in the recovery of areas degraded by floods (Bohrer et al. 2009). It is also used in traditional medicine a diuretic, emetic remedy as well as in inhalations, control of uterine inflammation and anemia (Guedes et al. 2014). In the phytochemical screening of extracts from various parts in plants of this genus, metabolites with broad biological performance were identified, such as antioxidant (Lianhe et al. 2012), anti-inflammatory (Ganga et al. 2012), antimicrobial (Mutai et al. 2013; Guedes et al. 2014), cytotoxicity (Saha et al. 2013), photoprotective (Martins et al. 2016), among others. Souza et al. (2015) argue that plant parts may present different chemical compositions and consequently different biological activities.

According to the chromatographic methods, isoflavonoids are the main constituent metabolites of D. ecastaphyllum, namely biochanin A, daidzein, dalbergin, formononetin, isoliquiritigenin, medicarpin, 3-Hydroxy8,9-dimethoxypterocarpan and liquiritigenin (Donnelly et al. 1973; Matos et al. 1975; Daugsch et al. 2008; Piccinelli et al. 2011). Some of these compounds have also been identified in samples of red propolis whose chemical profile $D$. ecastaphyllum is indicated as the botanical origin of this bee product (Mendonça-Melo et al. 2017).

Many studies have identified and elucidated numerous biological actions of red propolis (Rufatto et al. 2017); however, few studies have investigated its primary source. Although some studies have investigated D. ecastaphyllum, its bioactive compounds, microbiological quality and antioxidant activity are not well known. This study evaluated and compared microbiological quality, chemical composition and antioxidant activity of stem and leaf samples of D. ecastaphyllum.

\section{Materials and Methods}

Sampling

Samples of stems $(\mathrm{n}=5)$ and leaves $(\mathrm{n}=5)$ of D. ecastaphyllum (L.) Taub. were collected in February 2015 in different sites in the municipalities of Canavieiras $\left(15^{\circ} 40^{\prime} 30^{\prime} \mathrm{S}\right.$, $\left.38^{\circ} 56^{\prime} 50^{\prime \prime} \mathrm{W}\right)$ and Ilhéus $\left(14^{\circ} 47^{\prime} 20^{\prime \prime} \mathrm{S}\right.$, $\left.39^{\circ} 02^{\prime} 58^{\prime \prime} \mathrm{W}\right)$ in the state of Bahia, Brazil, located in the region with phytophysiognomy of the Atlantic Forest and mangrove vegetation. The sampling sites were linked to the environment of red propolis apiaries. For each site, a plant was selected randomly to collect samples of stems with $10 \mathrm{~cm}$ in length $X 3 \mathrm{~cm}$ in diameter and adult leaves. These samples were dried in air circulating greenhouses $\left(40^{\circ} \mathrm{C}\right)$ for $72 \mathrm{~h}$ and then ground in knife mill.

The specimens were herborized and sent to the Herbarium of the Federal University of Recôncavo da Bahia (HURB), where they were identified and deposited in vouchers 11,507 and 11,509 , respectively, collected in the municipality of Canavieiras and Ilhéus.

\section{Microbiological analyses}

Ten grams of the material in natura were weighed $90 \mathrm{ml}$ of sterile peptone saline solution and homogenized for $2 \mathrm{~min}$ in Stomacher Lab-Blender (Seward type 400, London, United Kingdom). For the quantification of the colony forming units of aerobic mesophilic microorganisms, using the methodology recommended by Silva et al. (2010) and for molds and yeasts in ISO 21527-2 (2008). The quantification of Coagulasepositive Staphylococcus and Clostridium Sulphite Reduction Spores was performed according to Bennett and Lancette (2001) and ISO 15213 (2003). The counts of coliforms and Escherichia coli were obtained by the SimPlate method (BioControl) and the detection of Salmonella spp. by the Immunodiffusion 1-2 Test (AOAC 2005).

\section{Chemical composition}

Hydro-alcoholic extract

In the extraction, $1 \mathrm{~g}$ of the dried and ground samples were used in $12.5 \mathrm{~mL}$ of $70 \%$ ethanol at constant shaking at room temperature for $14 \mathrm{~d}$. Afterwards, the samples were placed in ultrasonic bath (1h) and centrifuged at 3,000 rpm/10 min, filtered and evaporated under low pressure. After solvent evaporation and stability of samples weight, the dried extract was placed in a freezer 
$\left(-20^{\circ} \mathrm{C}\right)$. The extracts used in the analyses were solubilized in methanol at a concentration of $4 \mathrm{mg} /$ mL (Park et al. 1998).

\section{Fatty acids}

The profile of fatty acids in the samples was determined by gas-liquid chromatography with flame ionization detection (GC-FID at 260 ${ }^{\circ} \mathrm{C}$ ) according to Barros et al. (2013). A capillary column was used in DANI GC 1,000 (Izasa, Barcelona, Spain) instrument, equipped with a split/splitless injector, with a flame ionization detector (FID) and a Macherey-Nagel column (25 $\times 0.32 \mathrm{Mm}$ ID $\times 0.25 \mu \mathrm{m} \mathrm{df})$. The method involves the transesterification process, which consists of solubilization of samples in methanol, followed by the addition of sulfuric acid and toluene (at a ratio 2: $1: 1(\mathrm{v} / \mathrm{v} / \mathrm{v}))$ for at least $12 \mathrm{~h}$ in bath at $50{ }^{\circ} \mathrm{C}$ and $160 \mathrm{rpm}$. It was added $3 \mathrm{~mL}$ of deionized water and $3 \mathrm{~mL}$ of diethyl ether to this mixture for phase separation. After separation, the lipid phase was extracted, filtered on a column containing sodium sulphate and packed in an amber vessel.

The oven temperature ranged from $30^{\circ} \mathrm{C}$ to $220^{\circ} \mathrm{C}$, totaling $35.16 \mathrm{~min}$ per analysis. The gas (hydrogen) was kept at a flow rate of $4.0 \mathrm{~mL} / \mathrm{min}$ (0.61 bar), measured at $50^{\circ} \mathrm{C}$. A volume of $1 \mu \mathrm{L}$ of transesterified sample was injected into the GC. Fatty acids were identified by comparing the retention times relative to the peaks of standard FAME samples. The results were recorded and processed using CSW 1.7 software (DataApex 1.7, Prague, Czech Republic) and expressed as a relative percentage of each fatty acid calculated by internal normalization of the peak area of the chromatographic peak.

\section{Nutritional quality index of lipid fraction}

To assess the nutritional quality of lipids, we determined the Atherogenicity Index (IA), Thrombogenicity Index (IT) (Ulbricht \& Southgate 1991) and the relationship between hypocholesterolemic/hypercholesterolemic $(\mathrm{H} / \mathrm{H})$ (Santos-Silva et al. 2002).

Total phenols and total flavonoids

The total phenol content and total flavonoids of the methanolic extract of stems and leaves were determined by the colorimetric method, FolinCiocalteu (Singleton et al. 1999) and Aluminum Chloride (Alencar et al. 2007), respectively.
The extracts $(0.5 \mathrm{~mL})$ were mixed with $2.5 \mathrm{~mL}$ of Folin-Ciocalteu reagent (1:10) and $2.0 \mathrm{~mL}$ of $\mathrm{Na}_{2} \mathrm{CO}_{3}$ (4\% sodium carbonate). After incubation for $2 \mathrm{~h}$ at room temperature, absorbance at 760 $\mathrm{nm}$ was determined. The results were expressed as milligram equivalents of Gallic acid per gram of extract (mg GAE / g) from the standard curve $\left(y=0.0093 x+0.0287 ; R^{2}=0.9999\right)$. To obtain the total flavonoid content, $2 \mathrm{~mL}$ of the extract was mixed with $2 \mathrm{~mL}$ of $\mathrm{AlCl}_{3}$ ( $2 \%$ aluminum chloride). Absorbance was measured at $420 \mathrm{~nm}$ after $1 \mathrm{~h}$ of incubation at room temperature and the result expressed as milligram equivalent of quercetin per gram of extract ( $\mathrm{mg} \mathrm{QE} / \mathrm{g}$ ) from the standard curve $\left(y=0.0353 x+0.0073 ; R^{2}=0.9995\right)$.

\section{Identification of chemical compounds by LC / MS}

The identification of the chemical compounds in stem and leaf samples of D. ecastaphyllum were performed using Liquid Chromatography coupled to the LTQ Orbitrap $\mathrm{XL}^{\mathrm{TM}}$ mass spectrometer (Thermo Fischer Scientific, Bremen, Germany), controlled by LTQ Tune Plus 2.5.5, for the control and acquisition of the data the system Xcalibur 2.1.0. The mobile phase consisted of a system gradient: $0.1 \%$ formic acid in Milli-Q (A) water and HPLC-grade methanol (B). The separation was performed using the Gemini $\mathrm{C} 18$ reverse phase column $(250 \times 4.6 \mathrm{~mm}, 5 \mu \mathrm{m})$ of Phenomenex in negative mode, kept at $25^{\circ} \mathrm{C}$, the chromatographic data acquired by three channels of $280 \mathrm{~nm}, 320 \mathrm{~nm}$ and $360 \mathrm{~nm}$ readings and fractions to the UV profile display (Falcão et al. 2013).

\section{Antioxidant activity}

The antioxidant capacity was determined by the physical method, known as radical sequestering activity (DPPH), and the chemical method, based on the transfer of hydrogen atoms ( $\beta$-carotene/linoleic acid system) (Alves et al. 2010). Butylhydroxyanisole (BHA) and ascorbic acid, synthetic antioxidant and natural antioxidant respectively, were used as reference substances for both methods.

Free radical scavenging activity DPPH (1,1-diphenyl-2-picrylhydrazyl)

The measurement of the DPPH radical sequestering activity of methanolic extracts at different concentrations were performed according to methodology established by Barros et al. (2013). 
In this physical method, the reaction mixture consisted of $0.3 \mathrm{~mL}$ of the sample at different concentrations ( 0.004 to $0.4 \mathrm{mg} / \mathrm{mL})$ and $2.7 \mathrm{~mL}$ of the $0.5 \mathrm{mM}$ solution of DPPH in methanol. After incubation for $1 \mathrm{~h}$ at room temperature, the absorbance reading was performed at $517 \mathrm{~nm}$. The antioxidant activity was expressed by EC50, that is, the concentration that induces half the maximum effect.

\section{$\beta$-carotene bleaching assay}

The coupled oxidation of $\beta$-carotene/linoleic acid was performed according to Barros et al. (2013). In this chemical method, $5 \mathrm{mg}$ of $\beta$-carotene were weighed and diluted in $25 \mathrm{~mL}$ of chloroform. A 4-mL aliquot was added, and $80 \mu \mathrm{L}$ of linoleic acid and $800 \mu \mathrm{L}$ of Tween 20 were added. The reaction mixture was subjected to complete chloroform evaporation using a rotary evaporator, the residue obtained was redissolved in $200 \mathrm{~mL}$ of water Deionized, previously saturated with oxygen for 30 $\mathrm{min}$. Aliquots of $4.5 \mathrm{~mL}$ of the $\beta$-carotene/linoleic acid emulsion were mixed with $0.2 \mathrm{~mL}$ of $0.1 \mathrm{mg} /$ $\mathrm{mL}$ methanolic extracts. Emulsion oxidation was monitored spectrometrically (UV-visible - Unicam Hekios Alpha), absorbance was measured at $470 \mathrm{~nm}$ at the initial time $(\mathrm{t}=0)$ and after $2 \mathrm{~h}$ of incubation at $50^{\circ} \mathrm{C}$. The antioxidant activity (AA) was expressed by inhibition percentage in relation to the control (emulsion + methanol) after a 2-h incubation period.

\section{Statistical analyses}

The experimental results were presented as means \pm standard deviation. For the inferential analysis, normality was verified by the ShapiroWilks test and the variance homogeneity by the Levene's and Bartlett's tests. The unpaired Student $t$-test was used to compare the differences between the means of treatment groups (stem and leaf), when values were within the normal distribution (fatty acids, phenol content, DPPH and $\beta$-carotene/Linoleic acid) or the non-parametric Mann-Whitney test, when values did not fit into the normal distribution (flavonoid content and microorganism counts). The multivariate analysis of canonical correlation was performed to establish correlation between two groups of variables, that is, the group formed by the content of phenols and flavonoids with the second group formed by the different antioxidant methods in stems and leaves ( $\beta$-carotene/linoleic acid and DPPH). The first group represents the dependent variables $(\mathrm{Y})$, while the second group represents the independent variables $(\mathrm{X})$. The Hotelling multivariate test (approximation of the $F$ distribution) was used to verify the significance of pairs of canonical variables (Johnson \& Wichern 1992). The variance percentage explained by the canonical variable was determined by the square of the canonical correlation. All analyses were performed in the statistical program $\mathrm{R}$ (version 3.3.0) at $5 \%(\mathrm{p}<0.05)$ significance level.

\section{Results and Discussion}

Microbiological analyses

As seen in Figure 1, the total colonyforming unit count for the mesophilic aerobic microorganisms (ranging to $9 \times 10^{3}$ to $2 \times 10^{5} \mathrm{cfu}^{-\mathrm{g}^{-1}}$ ), molds and yeasts (ranging to $2 \times 10^{2}$ to $3 \times 10^{4}$ cfu. $\mathrm{g}^{-1}$ ) (Mann-Whitney U test, $\mathrm{p}<0.00001$ ), were significantly higher in the stems than in the leaves of D. ecastaphyllum. Plants normally have a microbial load from the soil, water and air; however, as the stem is located in a more shaded and moist area of the plant, it has more favorable conditions for the proliferation of microorganisms (Huang et al. 2012).

The determination of fungi in vegetables and processed foods is of great importance due to risks to human and animal health, since some fungi produce toxic secondary metabolites. On the other hand, fungi such as endophytes, associated to medicinal plant tissues, may contain bioactive compounds economically useful to human health (Toghueo et al. 2017).

The count of aerobic mesophilic microorganisms, as well as of molds and yeasts, is commonly used as a general indicator of product quality. Total coliforms are also indicators of contamination during production, harvesting, and processing stages, and the best indicators are the presence of pathogenic microorganisms of enteric origin, such as Escherichia coli (Brasil 2010). No Escherichia coli, Staphylococcus spp., clostridium sulphite reducing spores and Salmonella spp. were found in the samples. The absence of these microorganisms indicates that plant tissues of $D$. ecastaphyllum are safe, from a microbiological viewpoint. This is important because these microorganisms are potentially pathogenic and of interest to public health (De-Melo et al. 2015).

Fatty acids

In the lipid composition of stems and leaves of D. ecastaphyllum, 21 types of methyl ester acids were identified, with higher percentages for 


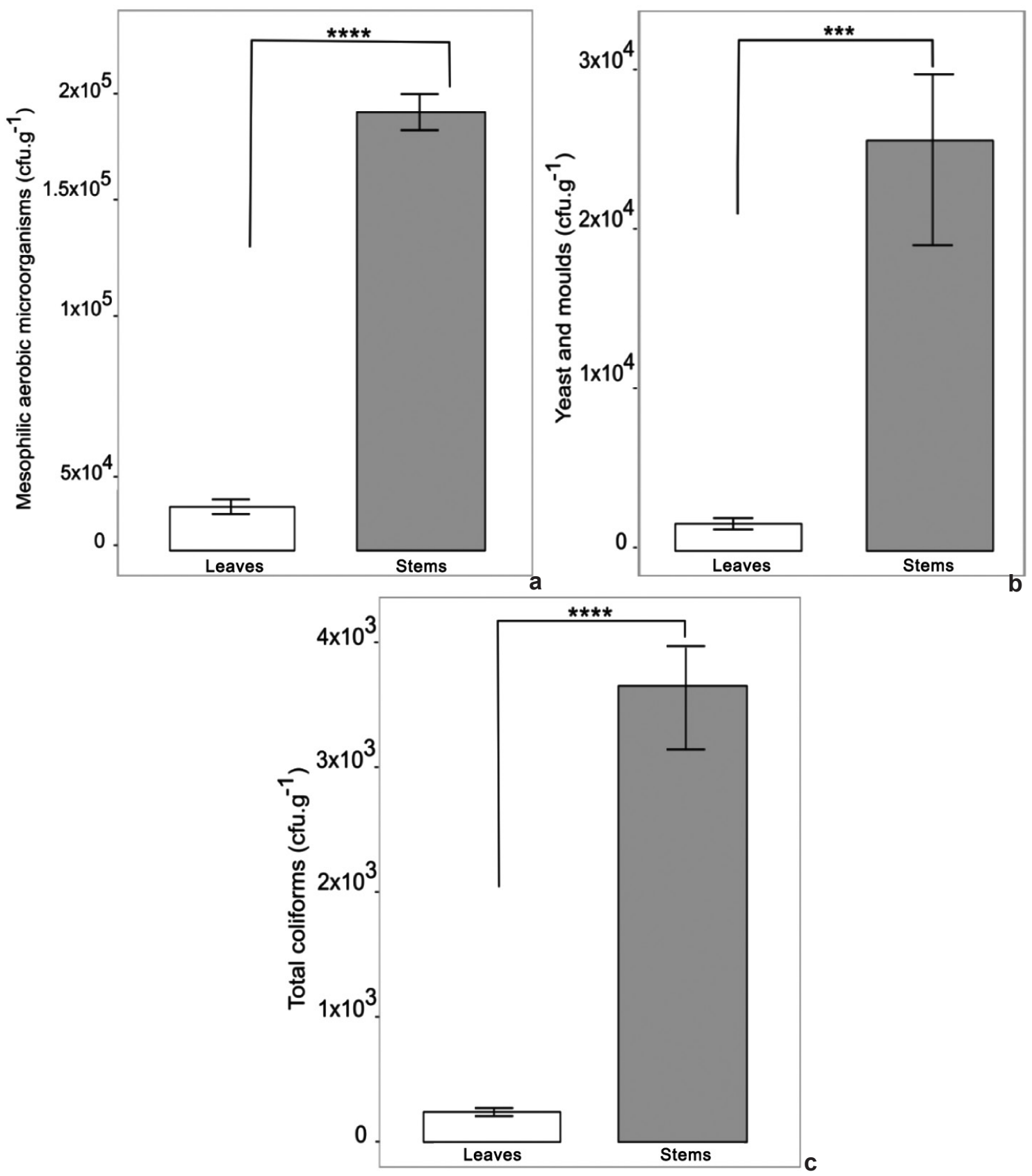

Figure 1 - a-c. Contamination level in leaves and stems samples of Dalbergia ecastaphyllum - a. of aerobic mesophilic microorganisms; $b$. of molds and yeasts; $c$. of total coliforms. Statistical significance was determined using the MannWhitney U test $(* * *: \mathrm{p}<0.001 ; * * * *: \mathrm{p}<0.0001)$.

saturated acids (SFA), followed by polyunsaturated fatty acids (PUFA) and monounsaturated fatty acids (MUFA). The amount of SFA in stems (58.81 $\pm 7.65 \%)$ was higher $(\mathrm{p}<0.05)$ than in leaves, PUFA were higher $(\mathrm{p}<0.05)$ in leaves $(46.06 \pm$ $4.43 \%$ ) than in stems, and for MUFA, there was no statistical difference between the samples. Among the SFA, C16: 0 (palmitic acid) presented higher levels and did not differ statistically between the samples. For PUFA, C18: 2n6c (linoleic acid) was more present $(p<0.05)$ in the stem $(24.50$ $\pm 5.16 \%$ ), while in the leaves the most abundant 
was C18: 3n3 (linolenic acid (41.54 $\pm 4.06 \%$ ). These PUFA contributed the highest percentage of omega-6 ( $\omega 6)$ in the stems and of omega-3 $(\omega 3)$ in the leaves (Tab. 1).

In a comparative study of leaves, stems and the entire plant of Ilex paraguariensis, C18: 3n3 was pronounced in leaves $(60.3 \pm 0.3 \%)$ and $\mathrm{C} 16$ : 0 was higher in stems $(25.2 \pm 1.8 \%$ ) (Souza et al. 2015), with difference in the chemical composition in the different plant parts. In this study, we also observed difference for C18: $3 \mathrm{n} 3$ between the stems and leaves, with the highest concentration observed in leaves. However, no difference was found in the C16: 0 content between the stems and leaves.

In D. odorifera T. Chen seed oils, C18: 2n6c was predominant when compared to C18: $3 \mathrm{n} 3$ (Lianhe et al. 2012). This result was similar to our study for stem samples of D. ecastaphyllum, while an inverse relationship for acids was observed in the leaves. These differences may be related to the characteristics of each species, as well as the soil and climatic conditions where the samples were collected.

Fatty acids are energetic sources and play important metabolic functions in the constitution of the cell membrane phospholipid bilayer, in regulating intracellular signaling pathways, transcription factors, and gene expression, as well as in the production of bioactive lipid mediators (Calder 2015). Among fatty acids, the palmitic acid is the most abundant in the human body and has the function of guaranteeing the physical properties of the cell membrane (Carta et al. 2017). It has also been reported as a precursor of the sapienic acid (C16: 1n10), which is present in sebaceous glands in the skin (Ge et al. 2003). Factors, such as excessive dietary carbohydrate and alcoholic beverages associated to a sedentary lifestyle, can trigger a dietary imbalance of C16: 0 with polyunsaturated acids, generating negative effects on human health (Carta et al. 2017).

The stems and leaves of $D$. ecastaphyllum evaluated in this study presented values that could improve the diet characteristics, although the leaves were nutritionally better $(\mathrm{p}<0.05)$ with higher PUFA: SAT ratio $(0.92 \pm 0.15)$ and lower ratio $n$ -6: $\mathrm{n}-3(0.10 \pm 0.03)$. The stems and leaves of $D$. ecastaphyllum evaluated in this study presented values that could improve the characteristics of the diet, although the leaves were nutritionally better ( $p$ $<0.05)$ with higher PUFA: SAT ratio $(0.92 \pm 0.15)$ and lower ratio $\mathrm{n}-6: \mathrm{n}-3(0.10 \pm 0.03)$. According to the Department of Health and Social Security of
London (United Kingdom) (1994) and Santos-Silva et al. (2002), foods with values lower than 0.45 PUFA: SAT favor the increase cholesterol levels in the blood and values higher than 4.0 n-6: n-3 ratio contribute to cardiovascular diseases. The presence of the omega- 6 and omega- 3 in polyunsaturated acids, respectively in the stem and leaf, contributed to the nutritional quality of the samples, since diets rich in these acids have a preventive action on diseases, such as cardiovascular diseases (Zhuang et al. 2018).

The AI (Atogenogenicity Index) and TI (Thrombogenicity Index) indexes in the leaves of D. ecastaphyllum were lower $(\mathrm{p}<0.05)$ than in the stems and an inverse relationship was found for the HH (Hypocholesterolemic/Hypercholesterolemic) index (Tab. 1). These indices indicate that diets with low AI and TI values may decrease the risk of coronary heart disease associated in isolation or synergy, respectively, with atherosclerosis and thrombosis (Ulbricht \& Southgate 1991; Souza et al. 2015). HH is directly related to cholesterol metabolism and studies on leafy vegetables have shown that $\mathrm{HH}$ are effective in reducing the hypercholesterolemic state in experimental models (Cheurfa \& Allem 2015). For these indices, no reference values have yet been established.

Total phenols and total flavonoids

The leaves had higher phenolic contents $(698.52 \pm 9.64 \%$, Student $t$-test, $\mathrm{p}=0.00001$, Fig. $2 \mathrm{a})$ and flavonoids $(47.51 \pm 2.21 \%$, Mann-Whitney test, $\mathrm{p}=0.00001$; Fig. $2 \mathrm{~b}$ ) than the stems did. Chaitra et al. (2015), analyzing the levels of phenolic compounds by spectrophotometric method with standards similar to that of this study, found higher values of phenols in stems (9.32 $\mathrm{mg} \mathrm{GAE} / \mathrm{g}$ ) than in leaves (8.54 mg GAE/g) of D. paniculata Rouxb. Similar result was reported for stem flavonoids (13.22 mg QE/g) of Grewia carpinifolia (Adebiyia et al. 2017). Liu et al. (2017) observed that the environment temperature could be a relevant factor to quantify phenol and flavonoid contents in the different plant parts, not obtaining, exclusively, a preponderant value for stems or leaves of the species Lycium chinense Miller.

Comparing the content of phenolic compounds in methanolic extracts of stems and leaves of $D$. ecastaphyllum with the ethanolic extract of red propolis from Sergipe state $(300.36 \pm 0.01 \mathrm{mg} \mathrm{GAE}$ $/ \mathrm{g}$ and $57.6 \pm 0.01 \mathrm{mg} \mathrm{QE} / \mathrm{g})$ and from Alagoas state $(197.77 \pm 0.01 \mathrm{mg} \mathrm{GAE} / \mathrm{g}$ and $58.19 \pm 0.01$ $\mathrm{mg} \mathrm{QE} / \mathrm{g}$ ) (Machado et al. 2016), there was a high 

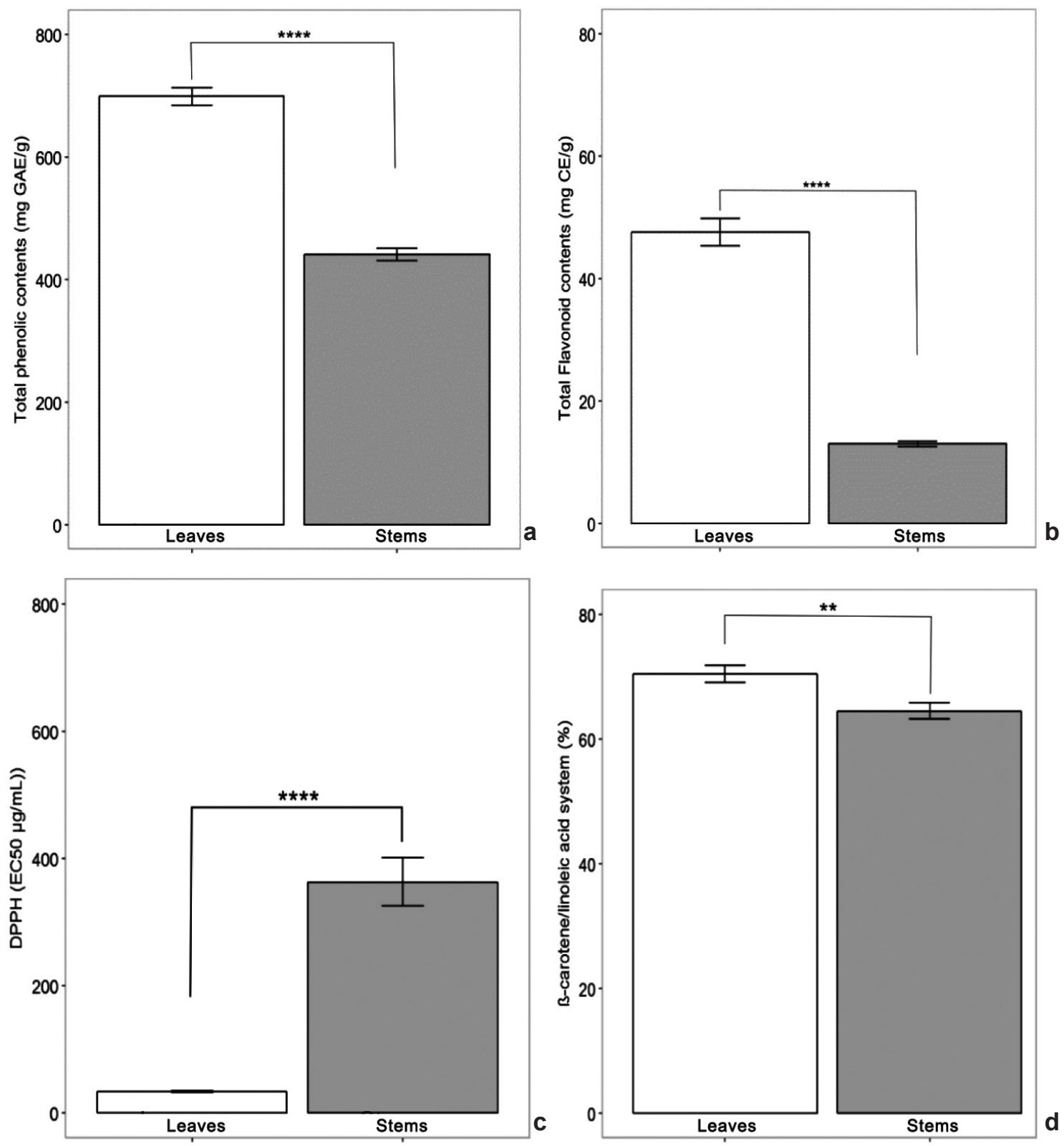

Figure 2 - a. Total phenol content; $b$. total flavonoid content; $c$. antioxidant activity of the stem and leaf extracts of Dalbergia ecastaphyllum by DPPH; d. $\beta$-carotene/linoleic acid. Statistical significance was determined using the Student $t$-test for the total phenol variables $(* * *: \mathrm{p}<0.0001)$ and $\beta$-carotene/linoleic acid $(* *: \mathrm{p}=0.01)$ and the Mann-Whitney U test for Variable total flavonoids $(* * * *: p<0.0001)$ and DPPH $(* * * *: p<0.0001)$. GAE $=$ Gallic acid Equivalent; $\mathrm{QE}=$ Quercetin Equivalent; DPPH =1,1-diphenyl-2-picrylhydrazyl; EC 50 = concentration that induces half the maximum effect.

concentration of methanolic extracts in the plant parts, mainly in the leaves, in relation to the propolis extract. These data corroborate the results in this study, indicating that the leaves are an important source of phenolic compounds.
The levels of total phenols and total flavonoids in our study were higher than those reported by Lianhe et al. (2012) and Chaitra et al. (2015) in other species of the genus Dalbergia and in red propolis. This fact can be associated with several 
Table 1 - Chemical composition of fatty acids in stem and leaf samples of Dalbergia ecastaphyllum. The results of the fatty acids were expressed in relative percentage. Averages followed by an asterisk (*) differ statistically by the Student $t$-test $(\mathrm{p}<0.05) ;{ }^{\mathrm{a}}=$ Standard deviation; ${ }^{\mathrm{b}}=$ Not found $;{ }^{\mathrm{c}}=$ Total saturated fatty acids; ${ }^{\mathrm{d}}=$ Total monounsaturated fatty acids; ${ }^{\mathrm{e}}=$ Total polyunsaturated fatty acids; ${ }^{\mathrm{f}}=$ Total omega- 6 fatty acids $;{ }^{\mathrm{g}}=$ Total omega- 3 fatty acids; $;{ }^{\mathrm{h}}=$ Proportion of polyunsaturated and saturated fatty acids; ${ }^{\mathrm{i}}=$ Proportion of omega- 6 and omega- 3 fatty acids; ${ }^{\mathrm{j}}=$ Atherogenicity index; ${ }^{\mathrm{k}}=$ Thrombogenicity index; ${ }^{1}=$ Relation of hypocholesterolemic / hypercholesterolemic fatty acid.

\begin{tabular}{|c|c|c|}
\hline \multirow{2}{*}{ Fatty acids } & Stems & Leaves \\
\hline & Mean $(\%) \pm \mathrm{SD}^{\mathrm{a}}$ & Mean $(\%) \pm \mathrm{SD}^{2}$ \\
\hline Caprylic Acid (C8:0) & $4.21 \pm 1.20^{*}$ & $2.57 \pm 0.70$ \\
\hline Lauric Acid (C12:0) & $0.69 \pm 0.40^{*}$ & $0.25 \pm 0.07$ \\
\hline Myristic Acid (C14:0) & $1.10 \pm 0.23$ & $0.96 \pm 0.11$ \\
\hline Pentadecanoic Acid (C15:0) & $0.65 \pm 0.10^{*}$ & $0.15 \pm 0.04$ \\
\hline Cis-10-Pentadecenoic Acid (C15:1 CIS-10) & $0.34 \pm 0.11$ & $\mathrm{NF}^{\mathrm{b}}$ \\
\hline Palmitic Acid (C16:0) & $38.19 \pm 4.47$ & $37.68 \pm 2.72$ \\
\hline Heptadecanoic Acid (C17:0) & $2.75 \pm 0.57^{*}$ & $1.04 \pm 0.24$ \\
\hline Cis-10-Heptadecenoic Acid (C17:1 CIS-10) & $\mathrm{NF}$ & $0.05 \pm 0.03$ \\
\hline Stearic Acid (C18:0) & $6.92 \pm 1.35^{*}$ & $5.26 \pm 0.96$ \\
\hline Oleic Acid (C18:1n9ct) & $2.50 \pm 1.51$ & $3.07 \pm 0.65$ \\
\hline Linolelaidic Acid (C18:2n6t) & $0.90 \pm 0.35$ & $\mathrm{NF}$ \\
\hline Linoleic Acid (C18:2n6c) & $24.50 \pm 5.16^{*}$ & $4.22 \pm 1.41$ \\
\hline Linolenic Acid (C18:3n3) & $11.02 \pm 2.29$ & $41.54 \pm 4.06^{*}$ \\
\hline Arachinic Acid (C20:0) & $1.59 \pm 0.65^{*}$ & $0.27 \pm 0.10$ \\
\hline Cis-11,14-Eicosadienoic Acid (C20:2 CIS) & $0.51 \pm 0.14$ & $\mathrm{NF}$ \\
\hline Cis-8,11,14-Eicosatrienoic Acid (C20:3n6) & $0.38 \pm 0.23$ & $\mathrm{NF}$ \\
\hline Eicosatrienoic Acid (C20:3n3) & $\mathrm{NF}$ & $0.30 \pm 0.20$ \\
\hline Behenic Acid (C22:0) & $0.97 \pm 0.53^{*}$ & $0.12 \pm 0.06$ \\
\hline Tricosanoic Acid (C23:0) & $0.60 \pm 0.32 *$ & $0.14 \pm 0.07$ \\
\hline Lignoceric Acid (C24:0) & $1.14 \pm 0.82 *$ & $0.39 \pm 0.13$ \\
\hline Nervonic Acid (C24:1) & $1.03 \pm 0.51$ & $\mathrm{NF}$ \\
\hline \multicolumn{3}{|c|}{ Sums and proportions of fatty acids } \\
\hline $\mathrm{SAT}^{\mathrm{c}}$ & $58.81 \pm 7.65^{*}$ & $50.82 \pm 4.28$ \\
\hline MUFA $^{d}$ & $3.87 \pm 1.75$ & $3.11 \pm 0.64$ \\
\hline PUFA $^{\mathrm{e}}$ & $37.32 \pm 6.49$ & $46.06 \pm 4.43^{*}$ \\
\hline Total & 100 & 100 \\
\hline$n-6^{f}$ & $25.78 \pm 5.16^{*}$ & $4.22 \pm 1.41$ \\
\hline$n-3^{g}$ & $11.02 \pm 2.29$ & $41.84 \pm 4.06^{*}$ \\
\hline PUFA:SAT ${ }^{\mathrm{h}}$ & $0.65 \pm 0.21$ & $0.92 \pm 0.15^{*}$ \\
\hline$n-6: n-3^{i}$ & $2.23 \pm 0.40^{*}$ & $0.10 \pm 0.03$ \\
\hline Nutrition & es of the lipid fractio & \\
\hline $\mathrm{AI}^{\mathrm{j}}$ & $1.15 \pm 0.30^{*}$ & $0.86 \pm 0.08$ \\
\hline $\mathrm{TI}^{\mathrm{k}}$ & $1.02 \pm 0.30^{*}$ & $0.32 \pm 0.03$ \\
\hline $\mathrm{HH}^{1}$ & $1.00 \pm 0.32$ & $1.27 \pm 0.14^{*}$ \\
\hline
\end{tabular}


Table 2 - Identification of chemical compounds in samples of Dalbergia ecastaphyllum stems and leaves using LC / MS. L = Leaf; $\mathrm{S}=$ Stem.

\begin{tabular}{|c|c|c|c|c|c|}
\hline RT & {$[\mathbf{M}-\mathbf{H}]^{-}(\mathbf{m} / \mathbf{z})$} & Formulae & Tentative Identification & Class of compounds & Samples \\
\hline 2.41 & 289 & $\mathrm{C}_{15} \mathrm{H}_{14} \mathrm{O}_{6}$ & Catechin & Flavanol & $\mathrm{S}$ \\
\hline 2.43 & 289 & $\mathrm{C}_{15} \mathrm{H}_{14} \mathrm{O}_{6}$ & Epicatechin & Flavanol & $\mathrm{S}$ \\
\hline 2.87 & 387 & $\mathrm{C}_{20} \mathrm{H}_{20} \mathrm{O}_{8}$ & Pentamethoxy hydroxy flavonol & Flavanol & $\mathrm{S}$ \\
\hline 2.88 & 461 & $\mathrm{C}_{21} \mathrm{H}_{18} \mathrm{O}_{12}$ & Luteolin-O-glucuronide & Flavone & $\mathrm{L}$ \\
\hline 2.89 & 179 & $\mathrm{C}_{9} \mathrm{H}_{8} \mathrm{O}_{4}$ & Caffeic acid & Hydroxycinnamic acid & $\mathrm{S}$ \\
\hline 3.33 & 165 & $\mathrm{C}_{9} \mathrm{H}_{10} \mathrm{O}_{3}$ & Ethoxy benzoic acid & Hydroxybenzoic acid & $\mathrm{L}$ \\
\hline 3.33 & 133 & $\mathrm{C}_{4} \mathrm{H}_{6} \mathrm{O}_{5}$ & Malic acid & Organic acid & $\mathrm{L}$ \\
\hline 4.24 & 147 & $\mathrm{C}_{9} \mathrm{H}_{8} \mathrm{O}_{2}$ & Cinnamic acid & Hydroxycinnamic acid & $\mathrm{L}$ \\
\hline 4.42 & 207 & $\mathrm{C}_{10} \mathrm{H}_{8} \mathrm{O}_{5}$ & 7,8-Dihydroxy-6-methoxycoumarin & Hydroxycinnamic acid & $\mathrm{S} ; \mathrm{L}$ \\
\hline 6.55 & 169 & $\mathrm{C}_{7} \mathrm{H}_{6} \mathrm{O}_{5}$ & Gallic acid & Hydroxybenzoic acid & $\mathrm{S} ; \mathrm{L}$ \\
\hline 8.4 & 343 & $\mathrm{C}_{15} \mathrm{H}_{20} \mathrm{O}_{9}$ & Homovanilic acid-O-hexoside & Hydroxyphenylacetic acid & $\mathrm{S}$ \\
\hline 9.82 & 137 & $\mathrm{C}_{7} \mathrm{H}_{6} \mathrm{O}_{3}$ & Salicylic acid & Hydroxybenzoic acid & $\mathrm{L}$ \\
\hline 11.63 & 153 & $\mathrm{C}_{7} \mathrm{H}_{6} \mathrm{O}_{4}$ & Protocatechuic acid & Hydroxybenzoic acid & $\mathrm{S} ; \mathrm{L}$ \\
\hline 14.96 & 609 & $\mathrm{C}_{27} \mathrm{H}_{30} \mathrm{O}_{16}$ & Kaempferol-diglucoside & Flavonol & $\mathrm{L}$ \\
\hline 15.12 & 609 & $\mathrm{C}_{27} \mathrm{H}_{30} \mathrm{O}_{16}$ & Rutin & Flavonol & $\mathrm{S} ; \mathrm{L}$ \\
\hline 16.43 & 255 & $\mathrm{C}_{15} \mathrm{H}_{12} \mathrm{O}_{4}$ & Pinocembrin & Flavanone & $\mathrm{S}$ \\
\hline 17.89 & 593 & $\mathrm{C}_{30} \mathrm{H}_{26} \mathrm{O}_{13}$ & Tiliroside & Flavonol & $\mathrm{L}$ \\
\hline 19 & 447 & $\mathrm{C}_{21} \mathrm{H}_{20} \mathrm{O}_{11}$ & Kaempferol-3-O-glucoside & Flavonol & $\mathrm{S}$ \\
\hline 19.46 & 121 & $\mathrm{C}_{7} \mathrm{H}_{6} \mathrm{O}_{2}$ & 4-hydroxybenzaldehyde & Hydroxybenzaldehyde & $\mathrm{S}$ \\
\hline 20.13 & 593 & $\mathrm{C}_{27} \mathrm{H}_{30} \mathrm{O}_{15}$ & Kaempferol-3-O-rutinoside & Flavonol & $\mathrm{S} ; \mathrm{L}$ \\
\hline 24.82 & 435 & $\mathrm{C}_{21} \mathrm{H}_{24} \mathrm{O}_{10}$ & Phloridzin & Dihydrochalcone & $\mathrm{L}$ \\
\hline 26.12 & 579 & $\mathrm{C}_{27} \mathrm{H}_{32} \mathrm{O}_{14}$ & Naringin & Flavanone & $\mathrm{S}$ \\
\hline 26.65 & 447 & $\mathrm{C}_{21} \mathrm{H}_{19} \mathrm{O}_{11}$ & Kaempferol 7- O-glucoside & Flavonol & $\mathrm{L}$ \\
\hline 26.96 & 447 & $\mathrm{C}_{21} \mathrm{H}_{20} \mathrm{O}_{11}$ & Kaempferol-3-O-glucoside & Flavonol & $\mathrm{L}$ \\
\hline 27.03 & 593 & $\mathrm{C}_{30} \mathrm{H}_{26} \mathrm{O}_{13}$ & Tiliroside & Flavonol & $\mathrm{S}$ \\
\hline 29.9 & 289 & $\mathrm{C}_{15} \mathrm{H}_{14} \mathrm{O}_{6}$ & Catechin & Flavanol & $\mathrm{L}$ \\
\hline 29.9 & 289 & $\mathrm{C}_{15} \mathrm{H}_{14} \mathrm{O}_{6}$ & Epicatechin & Flavanol & $\mathrm{L}$ \\
\hline 32.39 & 271 & $\mathrm{C}_{15} \mathrm{H}_{12} \mathrm{O}_{5}$ & Naringenin & Flavanone & $\mathrm{S}$ \\
\hline 34 & 625 & $\mathrm{C}_{27} \mathrm{H}_{30} \mathrm{O}_{17}$ & Quercetin 3-sophoroside & Flavonol & $\mathrm{L}$ \\
\hline 35.8 & 223 & $\mathrm{C}_{11} \mathrm{H}_{12} \mathrm{O}_{5}$ & Sinapic acid & Hydroxycinnamic acid & $\mathrm{S} ; \mathrm{L}$ \\
\hline 39.14 & 595 & $\mathrm{C}_{27} \mathrm{H}_{32} \mathrm{O}_{15}$ & Naringenin-O-dihexoside & Flavanone & $\mathrm{L}$ \\
\hline 43.79 & 463 & $\mathrm{C}_{21} \mathrm{H}_{20} \mathrm{O}_{12}$ & Quercetin-3-O-glucoside & Flavonol & $\mathrm{L}$ \\
\hline 45.35 & 817 & $\mathrm{C}_{27} \mathrm{H}_{30} \mathrm{O}_{16}$ & $\begin{array}{l}\text { Kaempferol 3-diglucoside-7- } \\
\text { glucoside }\end{array}$ & Flavonol & $\mathrm{S} ; \mathrm{L}$ \\
\hline 48.7 & 255 & $\mathrm{C}_{15} \mathrm{H}_{12} \mathrm{O}_{4}$ & Isoliquiritigenin & Chalcone & $\mathrm{S}$ \\
\hline 50.05 & 253 & $\mathrm{C}_{15} \mathrm{H}_{10} \mathrm{O}_{4}$ & Daidzein & Isoflavonoid & $\mathrm{S}$ \\
\hline 51.2 & 479 & $\mathrm{C}_{21} \mathrm{H}_{20} \mathrm{O}_{13}$ & Myricetin-3-O-glucoside & Flavonol & $\mathrm{S}$ \\
\hline 51.48 & 283 & $\mathrm{C}_{16} \mathrm{H}_{12} \mathrm{O}_{5}$ & Bichanin A & Isoflavonoid & $\mathrm{S}$ \\
\hline 53 & 285 & $\mathrm{C}_{15} \mathrm{H}_{10} \mathrm{O}_{6}$ & Kaempferol & Flavonol & $\mathrm{S}$ \\
\hline 53.25 & 285 & $\mathrm{C}_{16} \mathrm{H}_{14} \mathrm{O}_{5}$ & Vestitone & Isoflavonoid & $\mathrm{S}$ \\
\hline
\end{tabular}




\begin{tabular}{cccccc}
\hline RT & ${\text { [M-H }]^{-}(\mathbf{m} / \mathbf{z})}$ & Formulae & Tentative Identification & Class of compounds & Samples \\
\hline 53.38 & 329 & $\mathrm{C}_{17} \mathrm{H}_{14} \mathrm{O}_{7}$ & Quercetin-dimethyl-ether & Flavonol & $\mathrm{L}$ \\
55.64 & 269 & $\mathrm{C}_{16} \mathrm{H}_{14} \mathrm{O}_{4}$ & Medicarpin & Isoflavonoid & $\mathrm{S} ; \mathrm{L}$ \\
56.38 & 285 & $\mathrm{C}_{15} \mathrm{H}_{10} \mathrm{O}_{6}$ & Kaempferol & Flavonol & $\mathrm{L}$ \\
56.64 & 301 & $\mathrm{C}_{15} \mathrm{H}_{10} \mathrm{O}_{7}$ & Quercetin & Flavonol & $\mathrm{S} ; \mathrm{L}$ \\
58.8 & 271 & $\mathrm{C}_{16} \mathrm{H}_{10} \mathrm{O}_{4}$ & Neovestitol & Isoflavonoid & $\mathrm{S}$ \\
58.91 & 271 & $\mathrm{C}_{15} \mathrm{H}_{12} \mathrm{O}_{5}$ & Naringenin & Flavanone & $\mathrm{L}$ \\
60 & 255 & $\mathrm{C}_{15} \mathrm{H}_{12} \mathrm{O}_{4}$ & Pinocembrin & Flavanone & $\mathrm{S} ; \mathrm{L}$ \\
60.2 & 267 & $\mathrm{C}_{16} \mathrm{H}_{12} \mathrm{O}_{4}$ & Formononetin & Isoflavonoid & $\mathrm{S} ; \mathrm{L}$ \\
61.07 & 271 & $\mathrm{C}_{16} \mathrm{H}_{16} \mathrm{O}_{4}$ & Vestitol & Isoflavonoid & $\mathrm{S}$ \\
63.09 & 315 & $\mathrm{C}_{33} \mathrm{H}_{38} \mathrm{O}_{20}$ & Quercetin-7-methyl-ether & Flavonol & $\mathrm{S}$ \\
63.11 & 313 & $\mathrm{C}_{16} \mathrm{H}_{12} \mathrm{O}_{6}$ & Luteolin 3'-methyl ether & Flavone & $\mathrm{L}$ \\
66.37 & 283 & $\mathrm{C}_{16} \mathrm{H}_{12} \mathrm{O}_{5}$ & Galangin-5-methyl ether & Flavonol & $\mathrm{L}$ \\
69.87 & 285 & $\mathrm{C}_{17} \mathrm{H}_{18} \mathrm{O}_{4}$ & (3S) -7-O-methylvestitol & Isoflavonoid & $\mathrm{S}$ \\
71.76 & 369 & $\mathrm{C}_{21} \mathrm{H}_{21} \mathrm{O}_{6}$ & Pinobanksin-3-O-hexanonate & Flavonol & $\mathrm{S}$ \\
73.94 & 353 & $\mathrm{C}_{16} \mathrm{H}_{18} \mathrm{O}_{9}$ & Chlorogenic acid & Hydroxycinnamic acid & $\mathrm{S}$ \\
76.57 & 435 & $\mathrm{C}_{21} \mathrm{H}_{24} \mathrm{O}_{10}$ & Phloridzin & Dihydrochalcone & $\mathrm{S}$ \\
\hline
\end{tabular}

factors, namely sample extraction and preparation procedures, seasonal variations, storage and quality of raw material (Rasheed et al. 2012).

\section{Identification of chemical compounds by LC/MS}

The chromatographic profile of extracts of stems and leaves of D. ecastaphyllum recorded at $280 \mathrm{~nm}$ and identification based on the deprotonated molecule, its fragmentations (MS) and comparison with molecular masses described in the literature are summarized in Table 2.

The LC/MS method allowed identification of 49 chemical compounds, of which $38 \%$ was compounds found exclusive in the stem, $30 \%$ in the leaf and $32 \%$ common to the samples. These compounds are distributed in 38 flavonoids and have phenolic acids. An organic acid (malic acid) was also detected in the leaf and aldehyde (4-hydroxybenzaldehyde) was observed in the stem. Among the flavonoids, the highest number of compounds are in the flavonols class $(n=18)$, followed by isoflavonoids $(\mathrm{n}=8)$, flavanones $(\mathrm{n}=5)$, flavanol $(\mathrm{n}=3)$, flavones and with less representation to chalcone $(\mathrm{n}=1)$ and dihydrochalcone $(\mathrm{n}=1)$. Only the flavones (derived from luteolin) were assimilated into the leaves. Isoflavonoids, formononetin, and medicarpin were present both in the stem and in the leaves.

Donnelly et al. (1973) and Matos et al.
(1975), analyzing the content of flavonoids in woody extract of the species D. ecastaphyllum, recorded the compounds formononetin $\left(\mathrm{C}_{16} \mathrm{H}_{12} \mathrm{O}_{4}\right)$, isoliquiritigenin $\left(\mathrm{C}_{15} \mathrm{H}_{12} \mathrm{O}_{4}\right)$, daidzein $\left(\mathrm{C}_{15} \mathrm{H}_{10} \mathrm{O}_{4}\right)$, vestitol $\left(\mathrm{C}_{16} \mathrm{H}_{16} \mathrm{O}_{4}\right)$, which were also found in this study. Few investigations have been carried out exclusively on D. ecastaphyllum and most are related in a comparative way to its resin with the chemical composition of red propolis. Several studies on chemical compositions show that resin of D. ecastaphyllum is the main raw material for Brazilian red propolis, mainly due to the presence of compounds like formononetin ( $\mathrm{m} / \mathrm{z} 267)$, biochanin $\mathrm{A}(\mathrm{m} / \mathrm{z} 283)$, pinocembrin ( $\mathrm{m} / \mathrm{z} 255)$, daidzein ( $\mathrm{m}$ / z 253), medicarpin ( $\mathrm{m} / \mathrm{z} 269$ ), isoliquiritigenin ( $\mathrm{m}$ / z 255), (Daugsch et al. 2008; Piccinelli et al. 2011; López et al. 2014; Mendonça-Melo et al. 2017).

In the other species of the genus Dalbergia, studies reported isoflavonoid fomononetin in the shell of D. melanoxylon (Mutai et al. 2013), pinocenbrin, liquiritigenin, galangin, naringenin and isoquiritigenin in ethanolic extracts of $D$. conchichinensis (Liu et al. 2016). biochanin A and genistein were the main compounds present in the leaves of D. odorifera (Zhang et al. 2011); however, in our study, biochanin A was only recorded in the stem. Catechin, epicatechin, luteolin, naringenin, quercetin, daidzein and the caffeic acid are considered antioxidant compounds (Cömert \& Gökmen 2018). 
Table 3 - Canonical correlation and canonical pairs between the variables (phenols, flavonoids and $\beta$-carotene / linoleic acid and DPPH) of the groups, stem and leaf of Dalbergia ecastaphyllum.

${ }^{\mathrm{a}}=1,1$ - Difenyl-2-picrylhydrazyl; ${ }^{* *}=\mathrm{p}<0.001 ;{ }^{\mathrm{ns}}=$ not significant $(\mathrm{p}<0.05) ;{ }^{\mathrm{b}}=$ Canonical correlation; ${ }^{\mathrm{c}}=$ Approximate value of the statistic $\mathrm{F} ;{ }^{\mathrm{d}}=\mathrm{Level}$ of significance.

\begin{tabular}{lcc}
\hline & \multicolumn{2}{c}{ Pair canonical } \\
\cline { 2 - 3 } Variables & $\mathbf{1}^{\mathbf{a}}$ Dimension & $\mathbf{2}^{\mathbf{a}}$ Dimension \\
\hline Phenols & 0.98 & 0.21 \\
Flavonoids & 0.96 & -0.27 \\
$\beta$ carotene/linoleic acid & 0.53 & 0.12 \\
DPPH $^{\mathrm{a}}$ & -0.88 & -0.02 \\
$\mathrm{r}^{\mathrm{b}}$ & 0.89 & 0.15 \\
$\mathrm{~F}^{\mathrm{c}}$ & $15.74^{* *}$ & $0.577^{\mathrm{ns}}$ \\
$\alpha^{\mathrm{d}}$ & 0.00 & 0.45 \\
\hline
\end{tabular}

In the stem and leaf samples of $D$. ecastaphyllum, promising compounds for human health were identified, such as formononetin, which has a potential effect on dermatitis attenuation (Li et al. 2018a), inhibition of cancer cell proliferation and metastasis (Zhang et al. 2018), neuroprotective (Li et al. 2018b) and antibactericidal properties (Mutai et al. 2015). Pinocembrin suppressed autophagy in melanoma cells (Zheng et al. 2018), demonstrating a protective effect on ischemia-induced brain injury (Tao et al. 2018) and neurovascular area with deficits related to Alzheimer's (Liu et al. 2014). Medicarpin could be used as a chemopreventive or cytotoxic agent for chemotherapeutic agents in resistant cancer cells (Gatouillat et al. 2015). Rutin reduced plasma and glucose levels associated to diabetes, it prevented degenerative changes in the heart, anti-inflammatory effect against intestinal diseases, anti-allergic properties against rhinitis and dermatitis, anti-tumor and antimicrobial features. These activities are linked mainly to the high antioxidant property of this compound (Gullón et al. 2017).

\section{Antioxidant Activities}

Antioxidants are substances capable of preventing and fighting oxidative damage caused by free radicals (Alves et al. 2010). Excess of these radicals could cause deleterious damage to mitochondria (Mailloux et al. 2014), plasma membrane (Neto \& Cordeiro 2016), and DNA deoxyribonucleic acid (Citron et al. 2016), triggering loss of cellular homeostasis and several pathogenic diseases (Alves et al. 2010).

Secondary metabolites produced by plants are sources of active principles with potential to block free radicals. They are of interest in the production of drugs, nutraceuticals, functional foods and food additives (Atanasov et al. 2015).

The methanolic extract of the leaves analyzed revealed a greater power reduction of the DPPH radical $(33.53 \pm 2.14 \mu \mathrm{g} / \mathrm{mL}$, Mann-Whitney test, $\mathrm{p}=0.00001$ ) (Fig. 2c) and better results for the $\beta$-carotene bleaching ( 70.37 $\pm 1.36 \%$, Student $t$-test, $\mathrm{p}=0.0034$ ) (Fig. 2d), compared to the stems. Reference substances, butyl hydroxyanisole (BHA) $(11 \pm 0.001 \mu \mathrm{g} /$ $\mathrm{mL})$ and ascorbic acid $(22 \pm 0.002 \mu \mathrm{g} / \mathrm{mL})$, have shown to be more efficient in the reduction $(\mathrm{p}<0.05)$ of DPPH. The $\beta$-carotene bleaching test showed that the antioxidant activity of BHA $(95.62 \pm 1.15 \%)$ was higher than in our extracts, while ascorbic acid was less expressive (43.63 $\pm 0.95 \%$ ).

The antioxidant activity of the hydroalcoholic extract of $D$. monetaria bark at a concentration of $5.46 \pm 0.17 \mu \mathrm{g} / \mathrm{mL}$ presented better DPPH sequestering efficacy than in this study (Martins et al. 2016). Ganga et al. (2012) observed that the free radical sequestering activity of the methanolic extract of $D$. paniculata leaf is related to the antiinflammatory action tested in rat edema. For the antiradicalar effect (DPPH), the EC50 value (70.6 $\mu \mathrm{g} / \mathrm{mL}$ ) found by these authors needed a higher concentration of methanolic extract of leaves 
of D. paniculata than the methanolic extract of leaves of D. ecastaphyllum $(33 \mu \mathrm{g} / \mathrm{ml})$.

The carotenoid $\beta$-Carotene helps in the inhibition of cellular lipid auto-oxidation; however, at high amounts of reactive oxygen species, it can undergo oxidation. The $\beta$-carotene/ linoleic acid system allows evaluating the ability of an antioxidant to protect $\beta$-carotene during the peroxidation of linoleic acid (Alves et al. 2010). Souza et al. (2015) also observed that extracts from leaves of $I$. paraguariensis prevented $\beta$-carotene degradation better than the stem extracts did.

The results of the multivariate analysis of canonical correlation show that the first canonical pair was significant $(\mathrm{p}<0.01)$ and with a high correlation value, which was used to interpret the data (Tab. 3). The results show that $89 \%$ of the variance between the groups of characteristics are explained by the canonical function 1 . Therefore, the contents of phenols and flavonoids presented a positive correlation with the $\beta$-carotene/linoleic acid method and a high negative correlation with DPPH. These results indicate, respectively, that the higher the phenolic compounds content, the greater the inhibition of lipid peroxidation and the lower the concentration of antioxidant in free radical sequestration DPPH.

The A canonical correlation analysis corroborates observations that the leaves showed better antioxidant activity, regardless of the method used, in comparison with the stems, which can be explained by the high content of phenolic compounds (Fig. 2a,b), the main secondary compounds of plants to control or delay the damage caused by free radicals to genetic material or lipid peroxidation (Farzaneh \& Oliveira 2015).

\section{Conclusion}

The stems and leaves of D. ecastaphyllum presented high levels of phenolic compounds and lipid contents with valuable acids, such as the linoleic and linolenic acids (omega family), respectively. The presence of the flavonoids formononetin, pinocembrin, kaempferol, rutin, naringenin and medicarpin among others characterizes chemical compositions that deserve attention, due to the versatility of pharmacological properties reported by the literature and antioxidant activity pointed out in this study. However, leaf samples showed significant higher results for total phenolic compounds and antioxidant activity when compared to stem samples. The absence of pathogenic bacteria in the samples is also a positive result.

The results indicate that the stems and leaves of D. ecastaphyllum have biological properties. Leaves are particularly better for functional food formulations and as natural antioxidant.

\section{Acknowledgements}

The authors thank the Coordenação de Aperfeiçoamento de Pessoal de Nível Superior (CAPES) by the sandwich doctorate (SWE) within the scope of the MEC/MCTI/CAPES/CNPq/ FAPs $n^{\circ}$ 09/2014 - Special Visiting Researcher; the Conselho Nacional de Desenvolvimento Tecnológico e Científico (CNPq); the Fundação de Amparo à Pesquisa do Estado da Bahia (FAPESB / PET 0022/2012); the Insecta Research Group of the Universidade Federal do Recôncavo da Bahia (UFRB). The Cooperativa de Apicultores de Canavieiras (COAPER) collaboration in the acquisition of samples. The Instituto Politécnico de Bragança (IPB-PT), the strategic programmer UID/ BIA/04050/2013(POCI-01-0145-FEDER-007569) funded by national funds through the Fundação para a Ciência e a Tecnologia (FCT), Portugal and by the European Regional Development Fund (ERDF) through the COMPETE2020-Programa Operacional Competitividade e Internacionalização (POCI).

\section{References}

Adebiyia OE, Olayemi FO, Ning-Hua T \& Guang-Zhi $\mathrm{Z}$ (2017) In vitro antioxidant activity, total phenolic and flavonoid contents of ethanol extract of stem and leaf of Grewia carpinifolia. Beni-Suef University Journal of Basic and Applied Sciences 6: 10-14.

Alencar SM, Oldoni TLC, Castro ML, Cabral ISR, CostaNeto CM, Cury JA, Rosalen PL \& Ikegaki M (2007) Chemical composition and biological activity of a new type of Brazilian propolis: red própolis. Journal of Ethnopharmacology 113: 278-283.

Alves CQ, David JM, David JP, Bahia MV \& Aguiar RM (2010) Métodos para determinação de atividade antioxidante in vitro em substratos orgânicos. Química Nova 33: 2202-2210.

AOAC (2005) Microbiological methods. In: Official methods of analysis. $16^{\text {th }}$ ed. Association of Official Analytical Chemists, Arlington. 246p.

Atanasov AG, Waltenberger B, Pferschy-Wenzig EM, Linder T, Wawrosch C, Uhrin P, Temml V, Wang L, Schwaiger S, Heiss EH, Rollinger JM, Schuster D, Breuss JM, Bochkov V, Mihovilovic MD, Kopp B, Bauer R, Dirsch VM \& Stuppner H (2015) Discovery and resupply of pharmacologically active plant-derived natural products: a review. Biotechnology Advances 33: 1582-1614. 
Barros L, Pereira E, Calhelha RC, Dueñas M, Carvalho AM, Santos-Buelga C \& Ferreira ICFR (2013) Bioactivity and chemical characterization in hydrophilic and lipophilic compounds of Chenopodium ambrosioides L. Journal of Functional Foods 5: 1732-1740.

Bennett RW \& Lancette GA (2001) Staphylococcus aureus. Ch.12, rev. Jan. 2001. In: FDA bacteriological analytical manual, $8^{\text {th }}$ ed. rev. AOAC International, Gaitherburg. Available at $<$ http://cfsan.fda.gov/ ebam/bam-12.html>. Access in Jan 2019.

Bohrer CBA, Dantas HGR, Gronemberger FM, Vincens RS \& Andrade SF (2009) Mapeamento de vegetação e do uso do solo no centro de diversidade vegetal de Cabo Frio, Rio de Janeiro, Brasil. Rodriguésia 60: 1-23.

Brasil - Ministério da Saúde - Agência Nacional de Vigilância Sanitária (2010) Farmacopeia brasileira. Vol 2. Anvisa, Brasília. 546p.

Calder PC (2015) Functional roles of fatty acids and their effects on human health. Journal of Parenteral and Enteral Nutrition 39: 1-15.

Carta G, Murru E, Banni S \& Manca C (2017) Palmitic acid: physiological role, metabolism and nutritional implications. Frontiers in Physiology 8: 1-14.

Carvalho AM (1997) A synopsis of the genus Dalbergia (Fabaceae: Dalbergieae) in Brazil. Brittonia 49: 87-100.

Chaitra S, Kumar NN, Shalini P \& Sharu Raj KM (2015) In vitro antioxidant activity of methanolic extracts of Dalbergia paniculata Roxb. International Journal of Pharmacy and Pharmaceutical Sciences 5: 938-944.

Cheurfa M \& Allem R (2015) Study of hypocholesterolemic activity of Algerian Pistacia lentiscus leaves extracts in vivo. Revista Brasileira de Farmacognosia 25: 142-144.

Citron BA, Ameenuddin S, Uchida K, Suo WZ, Santacruz K \& Festoff BW (2016) Membrane lipid peroxidation in neurodegeneration: role of thrombin and proteinase-activated receptor-1. Brain Research 15: $10-17$.

Cömert ED \& Gökmen V (2018) Evolution of food antioxidants as a core topic of food science for a century. Food Research International 105: 76-93.

Daugsch A, Morais CS, Fort P \& Park YK (2008) Brazilian red própolis - chemical composition and botanical origin. Evidence-based complementary and alternative medicine 5: 435-441.

Department of Health and Social Security (1994) Nutritional aspects of cardiovascular disease. Report on health and social subjects no 46. HMSO Her Majesty's Stationer Office, London. 178p.

De-Melo AAM, Estevinho MLMF \& Almeida-Muradian LB (2015) A diagnosis of the microbiological quality of dehydrated bee-pollen produced in Brazil. Letters in Applied Microbiology 61: 477-483.
Donnelly DMX, Keenan PJ \& Prendergast JP (1973) Isoflavonoids of Dalbergia ecastophyllum. Phytochemistry 12: 1157-1161.

Falcão SI, Tomás A, Vale N, Gomes P, Freire C \& Vilas-Boas M (2013) Phenolic quantification and botanical origin of Portuguese propolis. Industrial Crops and Products 49: 805-812.

Farzaneh V \& Oliveira IS (2015) A review of the health benefit potentials of herbal plant infusions and their mechanism of action. Industrial Crops and Products 65: 247-258.

Ganga RB, Madhu KP \& Vijaya RAD (2012) Investigation of antioxidant and anti-inflammatory activity of leaves of Dalbergia paniculata (Roxb). Asian Pacific Journal of Tropical Medicine 5: 455-458.

Gatouillat G, Magid AA, Bertin, E, Morjani H, Lavaud C \& Madoulet C (2015) Medicarpin and millepurpan, two flavonoids isolated from Medicago sativa, induce apoptosis and overcome multidrug resistance in leukemia P388 cells. Phytomedicine 22: 1186-1194.

Ge L, Gordon JS, Hsuan C, Stenn K \& Prouty SM (2003) Identification of the delta- 6 desaturase of human sebaceous glands: expression and enzyme activity. Journal of Investigative Dermatology 120: 707-714.

Gullón B, Lú-Chau TA, Moreira MT, Lema JM \& Eibes G (2017) Rutin: a review on extraction, identification and purification methods, biological activities and approaches to enhance its bioavailability. Trends in Food Science \& Technology 67: 220-235.

Guedes GMM, Albuquerque RS, Soares-Maciel RS, Freitas MA, Silva VA, Lima EO, Lima MA Cunha EVL \& Coutinho HDM (2014) Isolation of phytosterols of Dalbergia ecastophyllum (L.) Taub. (Leguminosae) and modulation of antibiotic resistance by a possible membrane effect. Arabian Journal of Chemistry: 1-5.

Huang L, Gao X, Liu M, Du G, Guo J \& Ntakirutimana T (2012) Correlation among soil microorganisms, soil enzyme activities, and removal rates of pollutants in three constructed wetlands purifying micro-polluted river water. Ecological Engineering 46: 98-106.

ISO 15213 (2003) Microbiology of food and animal feeding stuffs - Horizontal method for the enumeration of sulfite-reducing bacteria growing under anaerobic conditions. International Standards Organization, Winterthur. 12p.

ISO 21527-2 (2008) Microbiology of food and animal feeding stuffs - horizontal method for the enumeration of yeasts and moulds - part 2: colony count technique in products with water activity less than or equal to 0.95 . International Standards Organization, Winterthur. 17p.

Johnson RA \& Wichern DW (1992) Applied multivariate statistical analysis. $3^{\text {rd }}$ ed. Prentice-Hall, New Jersey. 642p. 
Li L, Wang Y, Wang X, Tao Y, Bao K, Hua Y, Jiang G \& Hong M (2018) Formononetin attenuated allergic diseases through inhibition of epithelialderived cytokines by regulating E-cadherin. Clinical Immunology 195: 67-76a.

Li Z, Zeng G, Zheng X, Wang W, Ling Y, Tang H \& Zhang J (2018) Neuroprotective effect of formononetin against TBI in rats via suppressing inflammatory reaction in cortical neurons. Biomed. Pharmacotherapy 106: 349-354b.

Lianhe Z, Xing H, Li W \& Zhengxing C (2012) Physicochemical properties, chemical composition and antioxidant activity of Dalbergia odorifera T. Chen seed oil. Journal of the American Oil Chemists' Society 89: 883-890.

Lima HC (2015). Dalbergia. In: Lista de Espécies da Flora do Brasil. Instituto de Pesquisas Jardim Botânico do Rio de Janeiro. Disponivel em $<$ http://floradobrasil.jbrj.gov.br/jabot/floradobrasil/ FB22908>. Acesso em mai 2018.

Liu S, Lin J, Hu C, Shen B, Chen T, Chang Y, Shih C \& Yang D (2017) Phenolic compositions and antioxidant attributes of leaves and stems from three inbred varieties of Lycium chinense Miller harvested at various times. Food Chemistry 215: 284-291.

Liu R, Li JZ, Song JK, Zhou D, Huang C, Bai XY, Xie T, Zhang X, Li YJ, Wu CX, Zhang L, Li L, Zhang TT \& Du GH (2014) Pinocembrin improves cognition and protects the neurovascular unit in Alzheimer related deficits. Neurobiology of Aging 35: 1275-1285.

Liu R, Wen X, Shao F, Zhang P, Huang H \& Zhang S (2016) Flavonoids from heartwood of Dalbergia cochinchinensis. Chinese Herbal Medicines 8: 89-93.

López BGC, Schmidt EM, Eberlin MN \& Sawaya ACHF (2014) Phytochemical markers of different types of red propolis. Food Chemistry 146: 174-180.

Machado BAS, Silva RPD, Barreto GA, Costa SS, Silva DF, Brandão HN, Rocha JLC, Dellagostin, OA, Henriques JAP, Umsza-Guez MA \& Padilha FF (2016) Chemical composition and biological activity of extracts obtained by supercritical extraction and ethanolic extraction of brown, green and red propolis derived from fifferent geographic regions in Brazil. Plos One 8: 1-26.

Mailloux RJ, Jin X \& Willmore WG (2014) Redox regulation of mitochondrial function with emphasis on cysteine oxidation reactions. Redox Biology 19: 123-139.

Martins FJ, Caneschi CA, Vieira JLF, Barbosa W \& Raposo NRB (2016) Antioxidant activity and potential photoprotective from amazon native flora extracts. Journal of Photochemistry and Photobiology B: Biology 161: 34-39.

Matos FJA, Gottlieb OR \& Andrade CHS (1975) Flavonoids from Dalbergia ecastophyllum. Phytochemistry 14: 825-826.
Mendonça-Melo L, Mota E, Lopez B, Sawaya A, Freitas L, Jain S, Batista M \& Araújo E (2017) Chemical and genetic similarity between Dalbergia ecastaphyllum and red propolis from the Northeastern Brazil. Journal of Apicultural Research 56: 1-8.

Mutai P, Heydenreich M, Thoithi G, Mugumbate G, Chibale K \& Yenesew A (2013) 3-Hydroxyisoflavanones from the stem bark of Dalbergia melanoxylon: Isolation, antimycobacterial evaluation and molecular docking studies. Phytochemistry Letters 6: 671-675.

Mutai P, Pavadai E, Wiid I, Ngwane A, Baker B \& Chibale K (2015) Synthesis, antimycobacterial evaluation and pharmacophore modeling of analogues of the natural product formononetin. Bioorganic \& Medicinal Chemistry Letters 25: 2510-2513.

Neto AJP \& Cordeiro RM (2016) Molecular simulations of the effects of phospholipid and cholesterol peroxidation on lipid membrane properties. Biochimica et Biophysica Acta 1858: 2191-2198.

Park YK, Ikegari M, Abreu JAS \& Alcici NMF (1998) Estudo da preparação dos extratos de própolis e suas aplicações. Ciência e Tecnologia de Alimentos 18: 313-318.

Piccinelli AL, Lotti C, Campone L, Cuesta-Rubio O, Fernandez MC \& Rastrelli L (2011) Cuban and Brazilian red propolis: botanical origin and comparative analysis by high-performance liquid chromatography-photodiode array detection/ electrospray ionization tandem mass spectrometry. Journal of Agricultural and Food Chemistry 59: 6484-6491.

Rasheed NMA, Nagaiah K, Goud PR \& Sharma VUM (2012) Chemical marker compounds and treir essential role in quality controlo f herbal medicines. Annals of Phytomedicine 1: 1-8.

Rufatto LC, Santos DA, Marinho F, Henriques JAP, Ely MR \& Moura S (2017) Red propolis: chemical composition and pharmacological activity. Asian Pacific Journal of Tropical Biomedicine 7: 591-598.

Saha S, Anisuzzman M, Islam MK, Mondal H \& Talukder C (2013) Antibacterial and cytotoxic potential of Dalbergia spinosa Roxb. leaves. International Journal of Pharmaceutical Sciences Review and Research 4: 512-515.

Santos-Silva J, Bessa RJB \& Santos-Silva F (2002) Effect of genotype, feeding system and slaughter weight on the quality of light lambs. II. Fatty acid composition of meat. Livestock Production Science 77: 187-194.

Silva N, Junqueira VCA, Silveira NFA, Taniwaki MH, Santos RFS \& Gomes RAR (2010) Manual de métodos de análises microbiológicas de alimentos e água. $4^{\mathrm{a}}$ ed. Varela, São Paulo. 632p.

Singleton VL, Orthofer R \& Lamuela-Raventos RM (1999) Analysis of total phenols and other oxidation substrates and antioxidants by means of FolinCiocalteu reagent. Methods in Enzymology 299: 152-178. 
Souza AHP, Corrêa RCG, Barros L, Calhelha RC, Santos-Buelga C, Peralta RM, Bracht A, Matsushita M \& Ferreira ICFR (2015) Phytochemicals and biactive properties of Ile paraguariensis: na invitro comparatives study between the whole plant, leaves and stems. Food Research International 78: 286-294.

Tao J, Shen C, Yanchun S, Chen W \& Gangfeng Y (2018) Neuroprotective effects of pinocembrin on ischemia/ reperfusion-induced brain injury by inhibiting autophagy. Biomedicine \& Pharmacotherapy 106: 1003-1010.

Toghueo RMK, Zabalgogeazcoa I, Vázquez de Aldana BR \& Boyom FF (2017) Enzymatic activity of endophytic fungi from the medicinal plants Terminalia catappa, Terminalia mantaly and Cananga odorata. South African Journal of Botany 109: 146-153.

Ulbricht TLV \& Southgate DAT (1991) Coronary heart disease: seven dietary factors. The Lancet 19: 985-992.
Zhang DY, Zu YJ, Fu YJ, Luo M, Gu CB, Wang W \& Yao XH (2011) Negative pressure cavitation extraction and antioxidant activity of biochanin $A$ and genistein from the leaves of Dalbergia odorifera $\mathrm{T}$. Separation and Purification Technology 83: 91-99.

Zhang J, Liu L, Wang J, Ren B, Zhang L \& Li $\mathrm{W}$ (2018) Formononetin, an isoflavone from Astragalus membranaceus inhibits proliferation and metastasis of ovarian cancer cells. Journal of Ethnopharmacology 221: 91-99.

Zheng Y, Wang K, Wu Y, Chen Y, Chen X, Hu CW \& Hu F (2018) Pinocembrin induces ER stress mediated apoptosis and suppresses autophagy in melanoma cells. Cancer Letters 431: 31-42.

Zhuang P, Wang W, Wang J, Zhang Y \& Jiao J (2018) Polyunsaturated fatty acids intake, omega-6/ omega-3 ratio and mortality: findings from two independent nationwide cohorts. Clinical Nutrition 38: 848-855. 